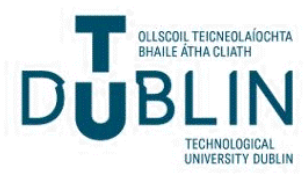

Technological University Dublin ARROW@TU Dublin

2013-6

\section{Cereal Grain Combustion in Domestic Boilers}

\author{
Andrew Keppel \\ Institute of Technology, Carlow \\ John Finnan \\ Teagasc Crops Research Centre \\ Bernard Rice \\ Teagasc Crops Research Centre
}

See next page for additional authors

Follow this and additional works at: https://arrow.tudublin.ie/itbenart

Part of the Environmental Engineering Commons

\section{Recommended Citation}

Keppel, A., Finnan, J., Rice, B., Owende, P., MacDonnell, K.: Cereal grain combustion in domestic boilers. Biosystems Engineering, vol. 115, Issue 2, June 2013, p.136-143. http://dx.doi.org/10.1016/ j.biosystemseng.2013.03.007.

This Article is brought to you for free and open access by the Energy at ARROW@TU Dublin. It has been accepted for inclusion in Articles by an authorized administrator of ARROW@TU Dublin. For more information, please contact arrow.admin@tudublin.ie, aisling.coyne@tudublin.ie, gerard.connolly@tudublin.ie. 
Authors

Andrew Keppel, John Finnan, Bernard Rice, Philip Owende, and Kevin MacDonnell

This article is available at ARROW@TU Dublin: https://arrow.tudublin.ie/itbenart/1 


\title{
Cereal Grain Combustion in Domestic Boilers
}

\author{
Andrew Keppel ${ }^{*}$, John Finnan ${ }^{2}$, Bernard Rice ${ }^{2}$, Philip Owende ${ }^{3,4}$ Kevin MacDonnell $^{3}$
}

1Department of Electronic, Mechanical and Aerospace Engineering, Institute of Technology Carlow, Kilkenny Road, County Carlow, Ireland.

2 Crops, Environment and Land Use Programme, Teagasc Crops Research Centre, Oak Park, Carlow, Ireland,

3 Biosystems Engineering, School of Agriculture and Food Science Centre and Veterinary Medicine, University College Dublin, Belfield, Dublin 4, Ireland,

4 Institute of Technology Blanchardstown, Blanchardstown, Road North, Dublin 15, Ireland

*Corresponding Author

Andrew Keppel

Department of Electronic, Mechanical and Aerospace Engineering Institute of Technology Carlow

Kilkenny Road, Carlow

Co. Carlow

Phone :

353599175440

Email:

andrew.keppel@itcarlow.ie 


\begin{abstract}
This study compared the combustion characteristics and the combustion behaviour of oats, barley, triticale and wheat to that of wood pellets. Sustained grain combustion in domestic boilers was feasible but problematic, the main impediment being clinker formation with ash agglomeration. Clinker formation was lowest for oats which burned easily with fewer operational problems. Triticale displayed reasonably good combustion characteristics and also ignited easily. In contrast, barley and wheat proved difficult to ignite while barley combustion was prone to self-extinguish. Thermal and combustion efficiency and heat output were considerably higher at a grain moisture content of $15 \%$ compared to a moisture content of $20 \%$. The efficiency of oat combustion was similar to that of wood pellets at a moisture content of $15 \%$. Carbon monoxide $(\mathrm{CO})$ emission from cereal grains increased with increasing moisture content, but was still below limit values. Oxides of nitrogen $\left(\mathrm{NO}_{\mathrm{x}}\right)$ emissions from cereal combustion were high and would require reduction by limiting the quantity of nitrogen applied to the crop and/or the use of air staging. Oats proved superior to the other grains as a combustion feedstock with similar efficiencies to those of wood pellets but low moisture content is a prerequisite for efficient grain combustion.
\end{abstract}

Keywords: grain combustion, wood pellets, ash agglomeration, carbon monoxide, oxides of nitrogen 


\section{Introduction}

European energy policy is underpinned by: the need to limit exposure to supply and price volatility of fossil fuels; to reduce greenhouse gas (GHG) emissions by using less, cleaner, and locally produced energy, including the possible integration of energy generation with waste management strategies, and; the need to create more competitive energy markets to stimulate innovation technology and jobs (EC, 2007). Therefore, the use of biomass and other renewable energy resources needs to be increased. The potential use of cereal grains as solid biomass fuel in compatible boilers has been the subject of renewed attention (EC, 2007; Bafver et al., 2009; Teagasc, 2008; Deswarte, 2006). The inherent potential stems from the need for a farm energy resource diversification strategy, mainly as a possible outlet for low quality and damaged grain arising from tighter EU legislation on feed grain quality (EC, 2007). It has also been argued that judicious use of grain as an energy feedstock may also facilitate controlled market intervention that is required to counter the impacts of unfavourable oil versus grain price fluctuations that are encountered from time-to-time (EC, 2007). It is recognized that due to frequent supply deficits in cereal grain markets, it may be unlikely that production for fuel will be a major consideration for growers. However, an increasing range of boiler designs in Europe currently include grains in the fuel range specification.

The suitability for combustion of a solid biomass fuel depends on several key factors, namely: energy value and efficiency of conversion, i.e. equivalent extractible heat value; unit cost of the fuel relative to other available fuels; relative operating cost of the associated energy conversion system (viz., running cost, equipment depreciation etc.), and; the ease and convenience factors associated with the energy conversion technology deployed. In this context, the value of cereal grain as a heating fuel depends on its suitability for combustion (viz., potential energy content, ash problems, GHG emissions and the restriction thresholds, and availability of compatible boilers), the market prospects for fuel grain, and the availability and supply logistics at the points of use The appealing factor of cereal grains 
for application as solid biomass fuel relates to their physical characteristics, specifically, uniform composition (Table 1), good flow characteristics in bulk storage, high bulk density, and the small and uniform particle size that may allow for combustion without the necessity of processing. For example, the energy density of grain (ca. $10 \mathrm{GJ} / \mathrm{m}^{3}$ at $15 \%$ moisture content) is approximately three times the value for woodchips, and therefore would require smaller storage space. The flow characteristics allow for easier handling into storage bins and simpler mechanisms for metering into the boiler during operation, which could facilitate automated control of fuel feeding mechanism for higher operation efficiency and requiring limited manual intervention.

The combustion of cereal residues and grains are well established at various operating scales (EC, 2007); on-farm domestic heating units, village heating systems and central power generating stations. Cereal grains are favourable as a fuel due to their higher heating value, better flow properties and lower ash contents compared to cereal residues (Lindström et al., 2007). Experimental cereal grain combustion trials on in Sweden (Bafver et al., 2009) have shown that the stack emissions are well within acceptable limits. Hartmann et al., (2008) carried out combustion tests with various cereal grains in two boilers suited for grain combustion and found that complete combustion of volatile gases could be achieved but that ash burn-out was problematic. They also noted high $\mathrm{NO}_{\mathrm{x}}$ emissions due to high nitrogen levels in the cereal feedstock. Vetter., (2006) evaluated cereal grain combustion in Germany and found that conventional wood burning boilers were inadequate for cereal combustion particularly in relation to particulate and $\mathrm{CO}$ emissions but that boilers specially designed for grain combustion gave acceptable levels of emissions. Lindstrom et al., (2007) investigated slagging characteristics in the combustion of cereal grains in a $20 \mathrm{kw}$ boiler and found large differences in slagging between different fuels with oats being best and wheat worst. Two possible areas for sustained application of heat from grain combustion are in:

(1) On-farm grain drying and domestic heating and grain drying and processing in merchant premises, which incur no extra cost in fuel storage and transport; 
(2) Medium-sized boilers (typically 0.1- 1.0 MW range; Keppel, 2010 ) which may not be in position to negotiate for favourable contracts for the supply of low-priced oil, coal or gas.

Increasing number of boilers are now designed for multiple solid biomass fuels, including woods (viz., sawdust, wood chip and pellets), cereals (viz., sunflower, rapeseed, waste grains such as wheat, oats etc.), energy crops such as miscanthus in loose and pelletized forms, and agro-process residues (e.g., rape cake, straw, and straw pellets). Notable manufacturers of boilers that are marketed as suitable for grain combustion include Passat Energy A/S (Denmark), Baxi (UK), Riley-Reka (UK), Biokompakt (Austria), Benekov(Czech Republic) and Guntamatic (Austria) among others. Grain burning boilers are not as advanced as those for wood chips; except for the more complex combustion-air distribution system that is required to efficiently burn the more densely packed fuel bed that can restrict movement of air required for complete combustion. Other problems associated with grain fuel combustion have generally been resolved such that efficient boilers are now available in the market, especially in Denmark and Austria. For example, impacts of the higher chlorine content that is associated with corrosion have been largely overcome by the use of corrosion-resistant materials, and corrosion prevention interventions using chemical additives such as limestone and kaolin (EC, 2007), but these measures add to capital and running costs. The leaching of cereal straws prior to combustion has also been found to reduce the $\mathrm{Cl}$ content to acceptable levels without compromising the quality of the solid biomass fuel (EC, 2007). Reduction of particulate and harmful emission (e.g., $\mathrm{HCl}, \mathrm{SO}_{2}$ and $\mathrm{NO}_{\mathrm{x}}$ ) resulting from high alkaline biomass combustion to acceptable levels via chemical additives are also promising (EC, 2007; Bafver et al., 2009)..

Objectives of this study were to quantify the combustion characteristics of cereal grains as solid biomass fuels and to study their combustion behaviour in full scale experiments in domestic boilers.

\section{Experimental Methods}

Grains from four cereal crops were used in these experiments, oats, barley, wheat and triticale. All the 
crops from which the experimental fuel samples were derived had been grown at Teagasc Crops Research Centre in Oak Park, Ireland using standard agricultural practice. The combustion characteristics of the experimental cereal grains were compared to those of standard commercial wood pellets of Canadian hardwood.

\subsection{Fuel Analysis}

The chemical and physical characteristics of the experimental cereal grain fuels were determined using the following standards; CEN/TS 14918 for calorific value, CEN/TS 14775 for ash content, CEN/TS 15103 for bulk density, CEN 15148 for volatile matter and CEN/TS 14774-2 for moisture content. Nitrogen content was measured using a Leco FP 328 Analyser (Leco ltd., St Joseph, Michigan, USA). Stoichiometric air, primary and secondary air requirements and the calorific value of char and volatile matter were calculated based on equations developed by Kalschmitt \& Hartmann, 2001.

\subsection{Boiler combustion experiments}

A commercially available boiler $(25 \mathrm{~kW}$ thermal capacity Benekov Pelling 27) was adapted to study the combustion characteristics of the fuels (BENEKOVterm s.r.o., Masarykova 402 79312 Horní Benešov, Czech Republic). This boiler has an integrated under-feed stoker with a fixed grate, and is marketed as being suitable for use with both wood pellets and cereal grain fuel. All combustion experiments were based, as far as possible, on the standards, ÖNORM M 7135 (Energy grain - Requirements and test specifications, national supplement referring to VORNORM ÖNORM CEN/TS 14961) and EN 303-5:1999 (Specifications for biomass combustion equipment-heating boilers for solid fuels, hand and automatically fired, nominal heat output of up to 300kW; Terminology, requirements, testing and marking; ECS, 1999). However, combustion experiments did not follow the standards in all respects as it was not practicable to conduct runs of 6hrs duration and all experiments were conducted at a load of $100 \%$ rather than at loads of $30 \%$ and $100 \%$. 


\subsubsection{Test procedure}

The boiler was retrofitted with thermocouples and a fuel hopper with load cells (Figure 1) to measure heat output and fuel throughput, respectively. The hopper was designed to fit within the fuel silo so as not to hinder the operation of the boiler, the hopper could accommodate $20 \mathrm{~kg}$ of fuel. Two load cells were attached symmetrically to the vertical supports of the hopper in order to quantify fuel throughput. The test procedure included: (a) Cleaning of debris and residual fuel purging from the hopper and grate surfaces, and cleaning of ash pan. The Benekov boiler lacked automated cleaning of the heat exchange surfaces, therefore, these were cleaned manually, every 3-4 hours to minimize

potential experimental error; (b) Charging the boiler with test fuel of known characteristics (weight, calorific value and ash content) and when necessary, recharging the hopper during tests; (c) Firing the boiler and when necessary, varying the primary or secondary air setting; (d) Experimental readings were taken once steady state was achieved, and all boiler tests lasted for 30 minutes after the steady state condition was attained; (e) The duration of each test was noted. The test boiler was checked for operational problems, e.g., agglomeration, clinker and fuel bridging problems.

During the combustion experiments, the thermal input and output were monitored in order to determine the thermal efficiency. The boiler thermal input was calculated using the net calorific value of the fuel and the mass throughput of fuel to the boiler. The boiler thermal output was calculated from the inflow and return temperatures of water through the boiler, the mass flow of water and the specific heat capacity of water. The mass flow rate of water was measured using a Siemens Ultraheat 2 WR5 ultrasonic heat meter (Siemens AG, Munich, Germany). The thermal efficiency of the boiler was calculated as the ratio of thermal output to input. The combustion tests were carried out at grain moisture contents of $15 \%$ and $20 \%$ wet basis with four replications. Harvested grain from each crop was dried down to $15 \%$ moisture, or wetted until it had attained a moisture content of $20 \%$. Combustion efficiency was calculated automatically by the gaseous emissions measuring equipment (see section 


\subsubsection{Monitoring and measurement of gaseous emissions}

Flue gas emissions were measured using a Testo 454 combustion analyser (Testo Instruments, Testostraße1, 79853 Lenzkirch, Germany) The device was calibrated as per the manufactures instructions, this consisted mainly of a gas purge cycle using air. prior to mounting of the bayonet probe at the sampling point in the chimney-stack. The probe was mounted orthogonal to the flow direction and at adequate distance ( $>5$ stack diameter lengths) from the last change in geometry, to ensure laminar flow at the point of measurement. The analyser used consists of a built in sampling pump that draws the flue gas from the gas-sampling probe, through a condensation trap and particle filter, and into the sensor chamber. Flue gas temperature was measured by a $\mathrm{K}$ type thermocouple located at the tip of the bayonet probe, while individual electrochemical sensors measure the concentration of specific gases. Emission constituents and characteristics measured included, $\mathrm{CO}, \mathrm{O}_{2}, \mathrm{NO}, \mathrm{NO}_{2}, \mathrm{H}_{2}$, and ambient air temperature. Calculated parameters included heat released from the combustion of the fuel, proportion of excess air required $(\lambda)$ and $\mathrm{CO}_{2} \cdot \mathrm{CO} 2$ was calculated by selecting the appropriate fuel type option on the combustion analyser. All the data was downloaded to a PC at the end of each measurement cycle.

\subsubsection{Monitoring of combustion characteristics of experimental fuels.}

The fuel was fired in the boiler and ignition sequence monitored and documented for each experimental 
sample. Subsequently, when the combustion process stabilized, the process was continually monitored for evidence of the onset of any undesirable combustion characteristics (combustion hot spots, increased stack emission, and ash related problems such as ash fusion and agglomeration/clinker formation). Agglomerates or clinker refer to the incombustible feedstock residue that accumulate on the grate surfaces (Kalschmitt and Hartmann, 2001). A method was developed to quantify the amount of clinker resulting from combustion of respective fuels. In this procedure combustion ash was mechanically shaken through a $3.15 \mathrm{~mm}$ screen for 20 seconds. The clinker index, $\mathrm{C}_{\mathrm{i}}(\%)$, was calculated as percent ratio of the mash of ash retained to the total mass of ash before sieving. A retention rate greater than $80 \%$ was adjudged as indicative of a high potential for clinker formation of the fuel in combustion.

Elemental compounds values, including $\mathrm{C}, \mathrm{H}, \mathrm{O}, \mathrm{P}, \mathrm{K}, \mathrm{S}, \mathrm{Cl}$ were obtained from literature (Kaltschmitt and Hartmann, 2001). Values provided by this source range from 43.5-43.6\% C, 6.4-6.5\% $\mathrm{H}$, 44.9$46.4 \% \mathrm{O}, 0.35-0.39 \% \mathrm{P}, 0.46-0.62 \% \mathrm{~K}, 0.11-0.12 \% \mathrm{~S}$ and $0.04-0.07 \% \mathrm{Cl}$. Primary and secondary air requirements are important parameters as they define is the amount of air required for complete combustion. Other key fuel reaction kinetic data such as stoichiometric air, primary and secondary air requirements, calorific value of char and volatile matter were calculated based on equations developed by (Kaltschmitt and Hartmann, 2001). The stoichiometric air requirement Sair was calculated as:

$\mathrm{S}_{\mathrm{air}}=4.77(0.01 \mathrm{C}+0.01 \mathrm{H} 2 / 4+0.01 \mathrm{O} 2 / 2)$

Where $\mathrm{C}, \mathrm{H} 2$ and $\mathrm{O} 2$ are the fraction components of the solid biomass sample Primary air was calculated as:

$\mathrm{P}_{\mathrm{air}}=\left(\mathrm{S}_{\mathrm{air}}(\mathrm{Fc} / 100)\right.$ 
Where $F c$ is the fraction of the char component

Secondary air was calculated as the difference between stiochometric air and

primary air.

\section{Results and Discussion}

\subsection{Fuel properties}

Physical, chemical and energy content of the tested fuels are shown in Table 2. Bulk densities of barley, triticale and wheat compared favourably with that of wood pellets although the bulk density of oats was substantially lower than that of wood pellets. Bulk density affects a number of factors in solid fuel combustion units, notably, the diameter of stoker auger (to prevent bridging), and the size and shape of the fuel hopper. It also affects the rate of combustion within the combustion chamber, i.e., as the bulk density increases, the void space decreases, therefore, so less air is available for combustion Ryu et al., (2006). Bulk density also affects the required fuel feed rate or throughput; therefore, the capacity of boilers to handle solid biomass fuels for maximum thermal utilization. Solid biomass fuels with varying moisture content can have a similar effect to bulk density, in that, as the moisture content increases the boiler may not have the reserve capacity to meet the heat demand. The moisture content of all cereal grains at harvest was considerably higher than that of wood pellets (Table 2). Similarly, the nitrogen content of all cereal grains were considerably higher than that of wood pellets which had a nitrogen content below the detection limit in this instance. Nitrogen contents ranged from $1.3 \%$ for barley to $1.8 \%$ for wheat and oats. In contrast, Carroll and Finnan (2012) reported the nitrogen contents of pellets made from a range of materials to be $0.36 \%$ (wood), $0.41 \%$ (willow), $0.43 \%$ (miscanthus), $0.53 \%$ (barley straw), $0.60 \%$ (wheat straw) and $0.63 \%$ (rape straw). Thus, the nitrogen contents of cereal grains are considerably in excess of other biomass feedstocks. Similarly, ash contents of all cereal grains were higher than that of wood pellets ranging from $1.7 \%$ for wheat to $2.9 \%$ for oats. Although high compared to wood pellets, the ash contents of cereal grains were lower than those of miscanthus or 
straw reported previously Carroll and Finnan, (2012). The gross calorific value of wood pellets was higher than those of all cereal grains (Table 2). Similarly, the net calorific value of wood pellets was considerably higher than all cereal grains reflecting the higher gross calorific value and the lower moisture content of wood pellets. Cereal grains were found to have a higher proportion of their energy in the char component and a lower volatile component compared with wood pellets (Table 2).

Volatile matter from solid biomass fuels includes light hydrocarbons, carbon monoxide, carbon dioxide, hydrogen, moisture, and tars. Their yields depends on the temperature and heating rate at the pyrolysis stage of the combustion process Ryu et al., (2006). The differences in volatiles among the experimental fuels were marginal (Table 3) and generally within the range of evidence from literature. The experimental data indicates that the volatiles accounted for approximately two-thirds of the fuel energy content. Values for fixed carbon (char) are presented in Table 3. Fixed carbon determines the necessary grate area for complete combustion; hence, the results indicate that different sizes of grate areas would be required for complete combustion of the experimental fuels (Saastamoinen et al., 2006). The air requirements for cereal combustion are shown in Table 3, the stoichiometric air requirements for cereal combustion were higher than the air requirements for wood combustion. Secondary air requirements for cereal combustion were similar to those of wood but the primary air requirements were higher than those of wood reflecting the additional air needed to burn the higher char component of cereals.

\subsection{Observed Combustion Characteristics}

Combustion-related problems such as ash fusion and agglomeration, and the requirement for frequent ash removal were experienced with some grains, notably wheat and barley. Cereal grains tended to form clinkers on the grate surface. Ash fusion manifested itself in two ways: firstly, fusion occurred due to poor combustion temperature control at the grate interface, which could be overcome by either air staging or by the use of water cooled grate (Jenkins et al., 1998), the principle of both 
techniques being to lower combustion temperatures below the ash melting temperature. As the amount of $\mathrm{CO}$ was reduced by oxidation, soot produced which deposited on the heat exchange surfaces, due to thermophoresis (Rohsenow et al., 1998), which is expected to further reduce the thermal efficiency by reducing the heat transfer coefficient (Bott, 1995).

Barley was extremely difficult to ignite, usually requiring 5 to 6 attempts before steady-state combustion could be achieved. Barley combustion was also prone to self-extinguishing and approximately $16 \%$ of the ash was clinker (Table 5). Wheat was also difficult to ignite, but once lit, few problems were encountered. Although wheat combustion produced 15\% clinker, this did not impede steady combustion and boiler performance as the clinker was easily dislodged by the fuel feeding system. Triticale displayed reasonably good combustion characteristics and also easily ignited. Once lit triticale burned with a strong and intense flame and the duty cycle (i.e. the period of time between maintenance such as manual ash removal) of this fuel was the longest of the cereals. Compared to the other cereal grains, oats burned easily with comparatively few operational problems. No boiler operational problems were encountered with wood pellets.

\subsection{Efficiency, Emissions and Clinker Formation}

Thermal and combustion efficiencies in addition to emission data is presented in Table 4. Wood pellet, the benchmark fuel, gave the highest heat output $(23 \mathrm{~kW})$ and thermal efficiency $(88.2 \%)$. Both thermal and combustion efficiencies were poor when cereal grains were burnt at $20 \%$ moisture. Efficiencies increased considerably when the cereal grains were burnt at a moisture content of $15 \%$. Triticale at $20 \%$ moisture fuel burned with a thermal efficiency of $82 \%$, which increased by $3 \%$ at the lower $15 \%$ moisture. Barley at $20 \%$ moisture was found to be very difficult to ignite and burn, and yielded the lowest thermal efficiency (45\%). Boiler thermal efficiency with barley fuel approximately doubled to $85 \%$ with drier fuel (15\% moisture). Wheat burned moderately well at 20\% moisture $(70 \%$ 
boiler thermal efficiency), but reduction in wheat fuel moisture content to $15 \%$ increased boiler thermal efficiency by $10 \%$. Oats burned reasonably well at a moisture content of $20 \%$. However, both thermal and combustion efficiencies were approximately equal to those of wood pellets when oats were burned at a moisture content of $15 \%$. Boiler output increased when grain was burned at a lower moisture content reflecting the reduction in moisture content. The highest boiler output at a moisture content of $15 \%$ was obtained from oats $(21 \mathrm{kw})$ and this output approached that of wood pellets with a moisture content of $<8 \%(23 \mathrm{kw})$.

In boilers feedstock moisture content is expected to influence heat release, stack emissions, accelerated corrosion of heat exchange surfaces, and the quantity of ash produced (Obernberger \& Thek, 2004). These impacts were observed when grains at higher moisture contents were fired, which is in agreement with Ebeling and Jenkins (1985). Moisture content was also the predominant factor limiting thermal efficiency; results in Table 4 show that a 5\% increase in moisture content, yielded approximately $31 \%$ reduction in thermal efficiency, on average. Values of excess air increased while stack temperatures decreased as the moisture content of the grain increased. Similarly, lower efficiencies and a higher amount of un-burnt material in the bottom ash were observered when grain was fired at a $22 \%$ moisture content Ronnbach, (2008).

Gaseous emissions are shown in Table 4. $\mathrm{CO}_{2}$ levels in the flue gases were generally low when cereal grain was burnt at $20 \%$ moisture indicating inefficient combustion but $\mathrm{CO}_{2}$ levels increased when grain was burnt at $15 \%$. Concentrations of carbon monoxide were all below the international standards which have been set for biomass combustion ECS, (1999). CO concentrations were higher when grain was burnt at a moisture content of $20 \%$ compared to a moisture content of $15 \%$. Oats burned with the lowest $\mathrm{CO}$ concentrations of all the fuels tested including wood. $\mathrm{CO}$ concentrations recorded when triticale, oats and wheat were burnt at $15 \%$ moisture were all lower than the strict emission standards of the German authorities (Verma et al., 2009) although CO concentrations during wood pellet combustion were higher than this standard. The effect of decreasing moisture content on emissions of $\mathrm{NO}_{\mathrm{x}}$ was 
inconsistent. $\mathrm{NO}_{\mathrm{x}}$ emissions from wood were somewhat higher but in the same range as those reported recently Verma et al., (2011a;2011b). However, $\mathrm{NO}_{\mathrm{x}}$ emissions from the combustion of all cereal grains at $15 \%$ moisture were all considerably higher than $\mathrm{NO}_{\mathrm{x}}$ emissions from wood pellet combustion but also higher than $\mathrm{NO}_{\mathrm{x}}$ emissions from the combustion of cereal straw pellets reported recently by Verma et al., (2011a and 2011b). $\mathrm{NO}_{\mathrm{x}}$ emissions were similar to levels reported previously for cereal grains by Hartmann et al., (2008). There are no internationally agreed standards for $\mathrm{NO}_{\mathrm{x}}$ emissions from combustion of solid biomass fuels, although Austria has recommended a standard of $150 \mathrm{mg} / \mathrm{MJ}$ (ECS, 1999). However, a number of voluntary standards (or labels) exist for biomass combustion in several European countries. Some of these labels include limit values for $\mathrm{NO}_{\mathrm{x}}$ emissions including the Swan Mark label in Scandinavian countries $\left(340 \mathrm{mg} \mathrm{m}^{-3} \mathrm{NO}_{\mathrm{x}}\right)$, the Blue Angel label in Germany $\left(150 \mathrm{mg} \mathrm{m}^{-}\right.$ ${ }^{3} \mathrm{NO}_{\mathrm{x}}$ ) and the UZ-37 label in Austria $\left(100 \mathrm{mg} \mathrm{m}^{-3}\right)$ (Verma et al. 2009). $\mathrm{NO}_{\mathrm{x}}$ emissions from all the cereal grains at 15\% moisture exceeded the Blue Angel and UZ-37 labels while all cereal grains with the exception of barley exceeded the $\mathrm{NO}_{\mathrm{x}}$ emission limits in the Swan Mark label. High $\mathrm{NO}_{\mathrm{x}}$ emissions from cereal combustion are a result of relatively high nitrogen concentrations in the grain which in turn is a consequence of the quantity of nitrogen applied to cereal crops. Thus, one strategy that could be employed to reduce grain nitrogen and thus $\mathrm{NO}_{\mathrm{x}}$ emissions from cereal combustion is to limit nitrogen application to cereal crops intended for combustion in order to achieve a balance between grain yield and low concentration of nitrogen (Lewandowski \& Kauter ,2003). $\mathrm{NO}_{\mathrm{x}}$ emissions from biomass combustion may also be reduced by using primary measures such as air staging (Van Loo and Koppejan, 2008). Although, $\mathrm{NO}_{\mathrm{x}}$ emissions from cereal combustion are always likely to be higher than $\mathrm{NO}_{\mathrm{x}}$ emissions from other feedstock's, cereal combustion is most likely to take place in rural areas where ambient levels of air pollutants are low. Consequently, $\mathrm{NO}_{\mathrm{x}}$ emissions from cereal combustion are unlikely to have a negative impact on human health and the environment in the local area.

\subsection{Clinker}


The proportion of clinker in ash increased with increasing moisture content (Table 5). Clinker did not occur when wood pellets were burnt but clinker formation took place during the combustion of all cereal grains. Of the cereal grains used in this study, clinker formation was lowest when oats were burnt but were highest for wheat and barley. Ronnback (2008) reported that oats have a higher ash melting temperature compared to other grains and that problems with slagging are rarely reported for oats. Lindstrom et al., (2007) characterised and weighed slag after oats, wheat, barley and rye had been burned under laboratory conditions. Oats showed a low and barley a moderate tendency to form slag while wheat and rye demonstrated high slagging tendencies. The addition of $2 \%$ lime reduced slagging in barley and totally eliminated it in wheat and rye due to the formation of high ash melting calcium/potassium phosphates. Similarly, Ronnback (2008) reported that the addition of 1-2\% lime was common for grain combustion in Denmark. Clinker formation could also be overcome by either air staging or by the use of water cooled grate (Jenkins et al., 1998), the principle of both techniques being to lower combustion temperatures below the ash melting temperature. An alternative to the addition of lime or the use of water cooled grates in the reduction or elimination of clinker formation may be the use of moving grate or tilting grate technology as small scale burners $(<25 \mathrm{kw})$ tend to have fixed grate combustion systems at present. 


\section{Conclusion}

Cereal grains have similar bulk densities to wood pellets but contain significantly higher concentrations of ash and nitrogen while moisture content at harvest is typically twice that of wood pellets. Cereal grains contain a higher proportion of their energy as char and a lower proportion of their energy as volatile components, this feature requires a larger grate area for combustion. Combustion behaviour depended on grain species and moisture content. Wheat and barley proved difficult to ignite and produced large amount of clinker whereas oats burned easily with few operational problems and low quantities of clinker, the combustion behaviour of triticale was intermediate between these two extremes. Increasing moisture had an adverse effect on combustion behaviour and heat output and CO

emissions. Although $\mathrm{CO}$ emissions were below limit values, high $\mathrm{NO}_{\mathrm{x}}$ emissions were a feature of cereal combustion. The combustion of oat grains at a moisture content of $15 \%$ compares favourably with wood pellet combustion but the combustion of other cereal grains is more problematic and may require more specialized technology. 
Acknowledgement. This work was supported by Walsh Fellowship of Teagasc Crop Research Centre, and Science Foundation Ireland under Grant Number 06/CP/E001. The assistance of Dr Andreas Frolich and Mr Padraig Brett is gratefully acknowledged. 


\section{References}

Bäfver, L.S., Rönnbäck, M., Leckner, B., Claesson, F. \& Tullin, C. (2009). Particle emission from combustion of oat grain and its potential reduction by addition of limestone or kaolin. Fuel Processing Technology, 90, 353-359.

Bott, T. R. (1995). Fouling of Heat Exchangers, Elsevier, PO Box 211, Amsterdam, The Netherlands. ISBN: 0-444-82186-4.

Carroll, J.P. \& Finnan, J. (2012). Physical and chemical characteristics of pellets from emergy crops and cereal straws. Biosystems Engineering, 112, 151-159.

Deswarte, F. (2006). Incinerating wheat grains: a bright idea or just hot air? Green Chemistry Network Newsletter, 25, pp 8. www.greenchemistrynetwork.org/newsletter/newsletter-25.pdf.

Accessed 1/7/2012.

Ebeling, J. M. \& Jenkins, B. M. (1985). Physical and chemical properties of biomass fuels. Transactions of the ASAE, 28(3), 898-902.

European Committee of Standardisation (ECS) (1999) 305-5. Part 5-Heating Boilers. Heating boilers for solid fuels, hand and automatically stoked, nominal heat output up to $300 \mathrm{kw}$-Terminology, requirements, testing and marking. CEN/TC 355. European Committee for Standardisation.

European Commission (EC). Communication from the commission to the European council and the European parliament. An Energy Policy for Europe, COM (2007) 1 Final, pp 27, EC Brussels, Belgium, p. 27. http://ec.europa.eu/energy/energy policy/doc/01_energy policy for_europe en.pdf. 
Accessed 1/7/2012.

Goldstein, I. S. (1981). Organic Chemicals from Biomass. CRC Press, Florida; pp. 9-19. http://naldc.nal.usda.gov/download/26182/PDF. Accessed 1/7/2012.

Hartmann, H., Robmann, P., Turowski, P. \& Ellner-Schuberth, F. (2008). Straw and grain fuels for residential heating. Landteknik, 63(1), 32-33.

Jenkins, B.M., Baxter, L.L. \& Miles, T.R. (1998). Combustion properties of biomass. Fuel Processing Technology, 54(1-3), 17-46.

Kaltschmitt, M.\& Hartmann, H. (2001). Energie aus Biomasse Grundlagen: Techniken und Verfahren. ISBN: 3-540-64853-4, Springer-verlag, Berlin, Heidelberg, New York.

Lewandowski, I. \& Kauter, D. (2003). The influence of nitrogen fertilizer on the yield and combustion quality of whole grain crops for solid fuel use. Industrial Crops and Products, 17(2), 103-117.

Lindstrom, E, Sandstrom, M., Bostrom, D. \& Ohman, M. (2007). Slagging Characteristics during Combustion of Cereal Grains Rich in Phosphorus. Energy Fuels, 21 (2), 710-717

Obernberger, I. \& Thek, G. (2004). Physical characterization and chemical composition of densified biomass fuels with regard to their combustion behavior. Biomass and Bioenergy 27(6), 653-669.

Keppel (2010) Characteristics of cereal grains and crop residues as solid biomass fuel. M.Eng. Sc thesis. University College Dublin. 
Rohsenow, W.M., Hartnett J.P. \& Cho, Y. I. (1998). Hand book of heat transfer (3rd ed.: McGrawHill Professional.

http://www.knovel.com/web/portal/browse/display?_EXT_KNOVEL_DISPLAY bookid=1626\&Vertic $\underline{\text { alID }=0}$. Accessed 1/7/2012.

Ronnback, M (2008) Development of test methods for non wood small scale combustion plants. Work packagae 3: State of the technology. In development of test methods for non-wood small scale combustion plants. Final report, report number 302 TR Nk I-1-23. http://www.sp.se/sv/index/services/ventilation/Documents/Development $\% 20$ of $\% 20$ test $\% 20$ methods $\% 2$ 0for $\% 20$ non $\% 20$ wood $\% 20$ small-scale $\% 20$ combustion $\% 20$ plants.pdf. Accessed 5/6/2012.

Ryu, C., Yang, Y. B., Khor, A., Yates, N. E., Sharifi, V. N.\& Swithenbank, J. (2006). Effect of fuel properties on biomass combustion: Part I. Experiments--fuel type, equivalence ratio and particle size. Fuel, 85(7-8), 1039-1046.

Saastamoinen, J., Huttunen, M., Kilpinen, P.;,Kjaldman, L.;Oravainen, H. \& Bostrom, S. (2006). Emission formation during wood log combustion in fireplaces - Part II: Char combustion stage. Progress in Computational Fluid Dynamics, 6(4-5), 209-216.

Teagasc. (2008). Cereal Grain as Fuel. In. Farm Diversification Manual. Teagasc (The Irish Agric. \& Food Development Authority): Carlow, Ireland, pp. 2124.http://www.teagasc.ie/publications/2012/1112/Farm_Energy_Manual.pdf. Accessed 1/7/2012.

Van Loo S, Koppejan J (2008) The handbook of biomass combustion and co-firing. ISBN 978-1-84407249-1. EARTHSCAN, London and Sterling, VA. 
Verma, V.K., Bram, S. \& de Ruyck, J. (2009). Small scale biomass heating systems: Standards, quality labeling and market driving factors-an EU outlook. Biomass and Bioenergy, 33, 1393-1402.

Verma, V.K., Bram, S., Gauthier, G. \& De Ruyck, J. (2011a).Evaluation of the performance of a multifuel domestic boiler with respect to the existing European standard and quality labels: Part-1. Biomass and Bioenergy, 35(1), 80-89.

Verma, V.K., Bram, S., Gauthier, G. \& De Ruyck, J. (2011b). Performance of a domestic pellet boiler as a function of operational loads: Part-2. Biomass and Bioenergy, 35(1), 272-279.

Vetter D.H.A (2006) (Energy utilization of cereals and pellets) Energetische verwertung von getreide und halmgutpellets. Thuringen Ministerium fur landwirschaft, Naturschutz und Umwelt. $\quad$ http://www.oeko.de/service/naturschutz/Dateien/TLL_Halmgutpellets_0506.pdf. Accessed 5/6/2012. 


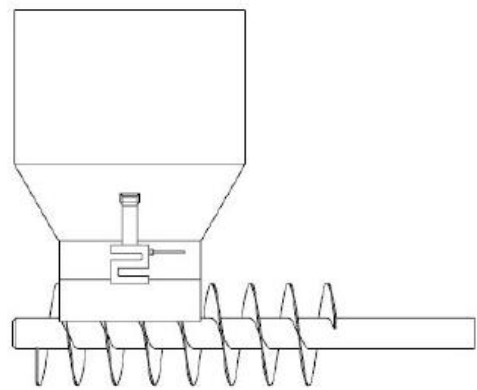

Elevation

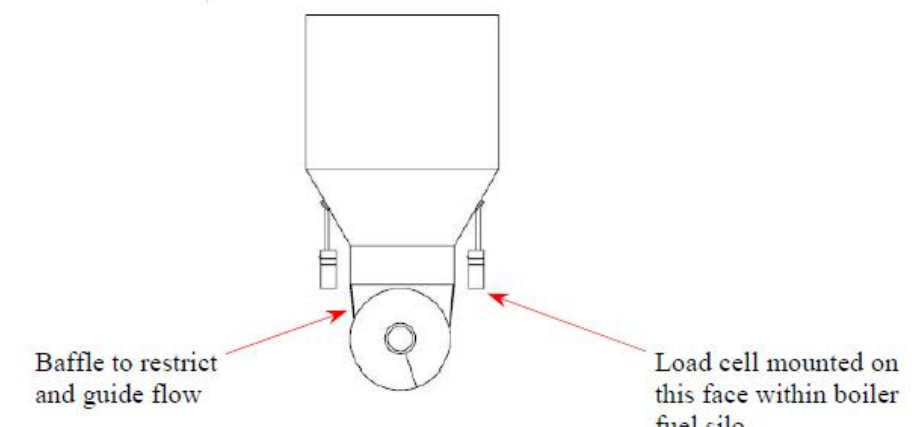

Plan view

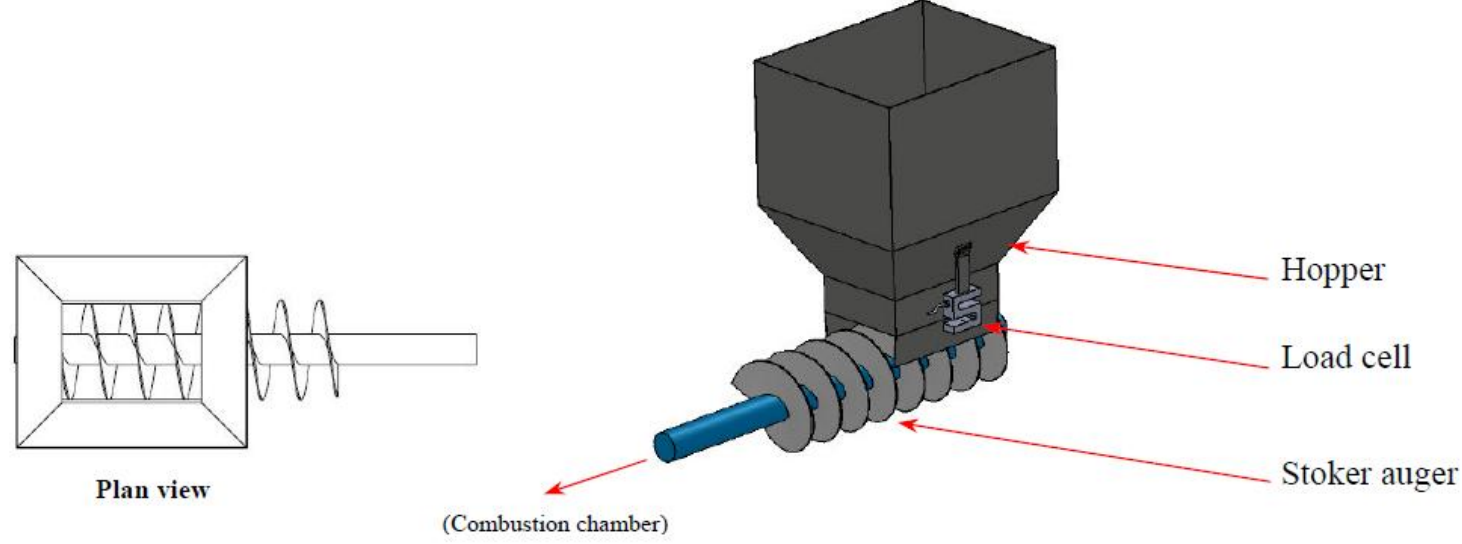
and guide flow this face

Figure 1 Hopper assembly showing load cell location

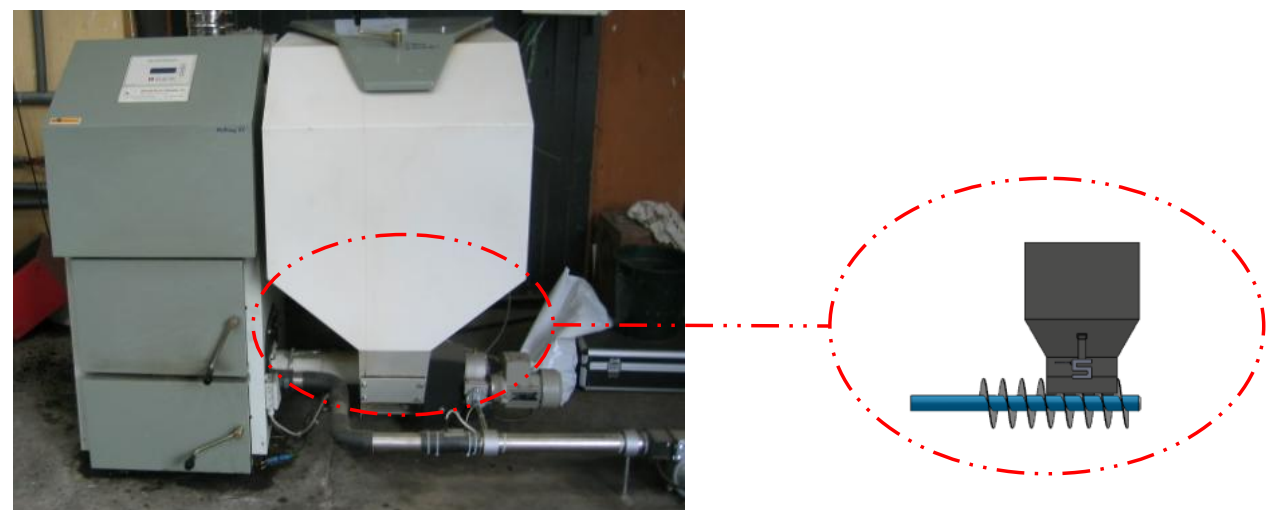

Figure 2 Location of hopper within Benekov boiler 
Table 1. Composition of various classes of biomass (Goldstein, 1981)

\begin{tabular}{lcccc}
\hline \multirow{2}{*}{ Biomass type } & \multicolumn{4}{c}{ Composition, \% dry weight } \\
\cline { 2 - 5 } & Cellulose & Hemicelluloses & Lignin & Starch \\
\hline Cereal Grain & - & - & - & $65-70$ \\
Grasses & $25-40$ & $25-50$ & $10-30$ & - \\
Softwood & $42 \pm 2$ & $27 \pm 2$ & $28 \pm 2$ & - \\
Cereal residues & 40 & 29 & 14 & - \\
\hline
\end{tabular}


Table 2 Physical, Chemical and Thermal Properties of Cereal Grains

\begin{tabular}{|c|c|c|c|c|c|c|c|c|}
\hline \multirow[t]{2}{*}{ Fuel sample } & \multirow{2}{*}{$\begin{array}{l}\text { Bulk } \\
\text { Density } \\
\mathrm{kg} / \mathrm{m}^{3}\end{array}$} & \multirow{2}{*}{$\begin{array}{c}\text { Moisture } \\
\text { content, } \\
\text { wet basis } \\
(\%)\end{array}$} & \multirow[t]{2}{*}{$\begin{array}{c}\text { Nitrogen } \\
\%\end{array}$} & \multirow[t]{2}{*}{$\begin{array}{c}\text { Ash content, } \\
\%\end{array}$} & \multicolumn{4}{|c|}{ Calorific values, $\mathrm{MJ} / \mathrm{kg}$} \\
\hline & & & & & $\begin{array}{l}\text { Gross } \\
\text { (dry) }\end{array}$ & $\begin{array}{c}\text { Net } \\
\text { (wet) }\end{array}$ & Char & Volatiles \\
\hline Barley & 663 & 18.8 & 1.3 & 2.06 & 18.46 & 13.55 & 7.73 & 10.73 \\
\hline Triticale & 680 & 19.1 & 1.7 & 2.01 & 18.32 & 13.38 & 8.2 & 10.11 \\
\hline Wheat & 718 & 18.2 & 1.8 & 1.67 & 18.28 & 13.52 & 8.06 & 10.22 \\
\hline Oat & 520 & 19.3 & 1.8 & 2.86 & 19.28 & 14.13 & 8.72 & 10.56 \\
\hline Wood pellet & 706 & 8.2 & - & 1.00 & 20.2 & 17.1 & 6.2 & 14.0 \\
\hline
\end{tabular}


Table 3 Volatile matter, fixed carbon content and air requirements of Dry Cereal Grains as dry

\begin{tabular}{lccccc}
\hline \multirow{2}{*}{ Fuel sample } & $\begin{array}{c}\text { Volatile content } \\
(\%)\end{array}$ & $\begin{array}{c}\text { Fixed carbon } \\
(\%)\end{array}$ & \multicolumn{3}{c}{ Air Requirements, kg air/kg fuel } \\
\cline { 4 - 5 } & & & Stoichiometric air & Primary air & Secondary air \\
\hline Barley & 78.5 & 19.5 & 1.04 & 0.20 & 0.84 \\
Triticale & 76.9 & 22.0 & 1.04 & 0.23 & 0.81 \\
Wheat & 77.0 & 18.0 & 1.08 & 0.26 & 0.81 \\
Oat & 76.3 & 20.9 & 1.34 & 0.28 & 1.06 \\
$\quad$ Wood pellet & 78.5 & 19.5 & 1.00 & 0.2 & 0.80 \\
\hline
\end{tabular}


Table 4 Conversion performance and measured stack emission in Benekov Pelling 27 Boiler trials

\begin{tabular}{|c|c|c|c|c|c|c|c|}
\hline \multirow[t]{2}{*}{ Fuel } & \multirow[t]{2}{*}{$\begin{array}{l}\text { Thermal } \\
\text { efficiency \% }\end{array}$} & \multirow[t]{2}{*}{$\begin{array}{c}\text { Boiler } \\
\text { output } \\
(\mathrm{kW})\end{array}$} & \multirow[t]{2}{*}{$\begin{array}{c}\text { Combustion } \\
\text { efficiency } \\
\%\end{array}$} & \multirow[t]{2}{*}{$\begin{array}{l}\text { Stack } \\
\text { gas } \\
\left({ }^{\circ} \mathrm{C}\right)\end{array}$} & \multicolumn{3}{|c|}{$\begin{array}{c}\text { Emissions } \\
\text { concentration }(\mathrm{CO}, \\
\mathrm{NO}_{\mathrm{x}} \mathrm{mg} / \mathrm{Nm}^{3} \text { at } 11 \% \\
\left.\mathrm{O}_{2} ; \mathrm{CO}_{2} \%\right)\end{array}$} \\
\hline & & & & & $\mathrm{CO}$ & $\mathrm{CO}_{2}$ & NOx \\
\hline \multicolumn{8}{|c|}{$\begin{array}{l}\text { Benekov Pelling } 27 \\
\text { (15\% cereal moisture content) }\end{array}$} \\
\hline Barley & 85 & 19.2 & 81 & 187 & 562 & 10.3 & 312 \\
\hline Triticale & 85 & 19.1 & 85 & 205 & 196 & 10.0 & 442 \\
\hline Wheat & 80 & 18.7 & 82 & 180 & 128 & 10.6 & 521 \\
\hline Oat & 87 & 21.0 & 87 & 212 & 112 & 10.6 & 419 \\
\hline Wood pellet & 88 & 23 & 84 & 226 & 275 & 11.4 & 76 \\
\hline \multicolumn{8}{|c|}{$\begin{array}{l}\text { Benekov Pelling } 27 \\
\text { (20\% cereal moisture content) }\end{array}$} \\
\hline Barley & 45 & 13.0 & 65 & 187 & 873 & 3.5 & 102 \\
\hline Triticale & 82 & 18.0 & 75 & 177 & 326 & 7.5 & 485 \\
\hline Wheat & 70 & 16.4 & 79 & 184 & 925 & 10.6 & 281 \\
\hline Oat & 73 & 16.0 & 81 & 177 & 158 & 8.6 & 487 \\
\hline Wood pellet & 88 & 23 & 84 & 226 & 275 & 11.4 & 76 \\
\hline
\end{tabular}


Table 5 Measured Agglomeration/Clinker Formation for Cereal Grains

\begin{tabular}{lcc}
\hline Feedstock & \multicolumn{2}{c}{ Proportion of clinker by fuel moisture content } \\
\cline { 2 - 3 } & $15 \%$ & $20 \%$ \\
\hline Barley & 11.3 & 16 \\
\hline Triticale & 5.2 & 7 \\
Wheat & 12 & 15 \\
Oat & 4 & 6 \\
Wood pellets & 0 & 0 \\
\hline
\end{tabular}

